\title{
Museer, kön och genus \\ - några reflektioner kring en närvarande frånvaro
}

\author{
MARIA BÄCKMAN* OCH SIMON EKSTRÖM*
}

Title: Museums, sex and gender - some reflections on a current absence.

Abstract: What is it that makes women and objects coded by women so often overshadowed in museums? And why is it so easy not to notice this fact? The article aims to discuss the amount of selection and de-selection that results in women only having a limited presence in the museum arena, so that they easily disappear from view - despite the fact that this is an absence that plays out before our very eyes. The starting point is a gender audit carried out in 2007 at the Museum of Ethnography in Stockholm, and the article provides a re-examination of some of the comments that came to light.

Key words: Museums, sex, gender, ethnographical museum, gender audit, exhibitions, collections, black boxes.

Våren 2007 blev vi, två etnologer från Stockholms universitet, tillfrågade om vi ville göra en genusgranskning av Etnografiska museets samlingar och utställningar. Initiativet till undersökningen var museets eget medan pengarna kom från Statens kulturråd. ${ }^{1}$ Det här är en artikel om den granskning som blev resultatet. Samtidigt är det en diskussion om något som mest av allt liknar ett trolleri. För hur var det möjligt för oss att gå varv på varv i museets utställningar utan att notera det som borde varit uppenbart från första början - att Etnografiska museet ägnade betydligt mer energi och möda åt att visa upp män och manliga sysslor än åt deras kvinnliga motsvarigheter. Det är en fråga som för oss rätt in i både detta och andra museers svarta lådor, dvs in i den box av självklarheter som gör att utställ- ningar och andra museala verksamheter så lätt tickar på utan att den kvinnliga frånvaron märks. Med detta sagt har vi också ringat in artikelns syfte. Avsikten är att diskutera de praktiker som gör att kvinnornas begränsade närvaro på den museala arenan så lätt försvinner ur sikte. Och detta trots att det är en frånvaro som utspelar sig framför våra egna ögon.

\section{EN OSYNLIG OSYNLIGHET}

Vi börjar med några ord om vår gemensamma museierfarenhet. Inte för att denna är så särdeles imponerande utan för att den råkar sammanfalla med ett långvarigt och professionellt intresse för genusfrågor. Bortsett från den redan omtalade genusgranskningen av Etnografiska museet har den ena av oss ett flerårigt 
84 förflutet på Nordiska museets Samdok-sekretariat. $^{2}$ Den andre har varit projektledare för den omarbetade basutställningen "Nordamerikas indianer" på Etnografiska museet, samt var dessutom under ungefär ett år involverad i utställningen ”(O)mänskligt. Om mänskliga kvarlevor på museer" vid samma museum.

Här och var i artikeln kommer denna äldre museierfarenhet att märkas i korta utblickar och exempel. Men i första hand är det ett senkommet återvändande till den ovan nämnda genusgranskningen på Etnografiska museet som utgör diskussionens egentliga underlag. ${ }^{3}$ Vad kom vi den gången fram till och vad identifierade vi som de mest pockande problemen? Låt oss alltså granska vår egen granskning.

När vi på museichefen Anders Björklunds uppmaning började "fältarbeta på museet" var vi först lite oroliga för om vi skulle hitta något att säga. Vi vandrade genom utställningarna och tittade på föremål, läste på skyltar, noterade intressanta metakommentarer kring kolonial etnocentrism och ett reflexivt historiebruk. Vad skulle vi kunna tillägga? Den här lite besvärande känslan av att inte kunna bidra med något substantiellt höll i sig under de två första varven genom utställningarna. Sedan började den smygande ersättas av en annan sorts oro, nämligen hur vi skulle kunna föra fram att så mycket återstod att göra vad gäller införlivandet av ett genusperspektiv på samlingarna och utställningarna. Och, rent konkret, vart hade egentligen kvinnorna tagit vägen i de här utställningarna? Var fanns de kvinnliga föremålen och de kvinnliga sysslorna? Det intressanta är just avståndet mellan dessa båda intryck. Vi är båda två sedan länge skolade i att tänka kring genus och representationer av kvinnlighet och manlighet. Varför hade vi inte redan från början sett det som några timmar senare framstod som så tydligt?
Den här känslan av att inte se - eller snarare av att ta över någon annans blick - har med tiden framstått som en allt viktigare tankeställare. Vad var det, frågade vi oss själva, som hände vid de där första rundturerna. Varför såg vi inte att kvinnorna liksom fattades? Det mest uppenbara svaret på den frågan är att utställningarna faktiskt fungerade, att de framstod som rimliga och, inte minst, självklara i sin egen rätt. Enskilda utställningar var intressanta, genomarbetade, vackra och tankeväckande på ett sådant sätt att den relativa frånvaron av kvinnor och kvinnliga domäner helt stillsamt försvann ur sikte.

Ofta är det i denna självklarhet som en genusanalys får ta sin utgångspunkt (jfr Grahn 2000, 2006). Och det är samtidigt på grund av allt det självklara som ett köns- och/eller genusperspektiv kan vara så svårarbetat. Hur som helst gav vårt första positiva intryck oss en tankeställare. För samtidigt insåg vi ju förnuftsmässigt att utställningarna till överväldigande grad kretsade kring vad män hade gjort. Föremålen var betydligt oftare hämtade från en manlig sfär. Det fanns så gott som ingen diskussion om relationer eller hierarkier mellan män och kvinnor; om olika former av kulturellt och historiskt konstruerade manligheter och kvinnligheter; eller om det inbördes statusförhållandet mellan sådana genusformer. Lika lite som vi kunde notera några spår av ett intresse för hur kön är något som bärs upp av förväntningar och manifesteras i handlingar. Men det var alltså fullt möjligt att inte lägga märke till detta, till och med för ett jämförelsevis tränat öga.

$\mathrm{Vi}$ förstod att någonstans $\mathrm{i}$ museets egen verksamhet dolde sig den eller de omständigheter som gjorde denna illusion möjlig. Dessutom var det uppenbarligen fråga om en logik som var så stark att även en så väsentlig 
kulturell ordning som genus nästan inte alls behövde ordas om och därmed heller inte framstod som riktigt viktig. Fortfarande så här långt efteråt tycker vi att det är smått fantastiskt. Det är verkligen - ett trolleri. Men innan vi går vidare med att försöka identifiera vad det är som gör illusionen så framgångsrik ska vi börja med några klargöranden. Vad är till exempel en genusgranskning av ett museum och hur går en sådan till?

\section{EN OMVÄND BÖRJAN}

Ibland måste man som bekant börja i det till synes perifera för därifrån ta sig dit man vill komma. På Etnografiska museet finns en utställning som med olika uppdateringar fortsatt att locka besökare under nästan tjugo år. Det är "Världen i kappsäcken” som på många sätt är kongenial med själva museet. Här väcks frågan om vad det är för ting och berättelser som samlare av olika slag har burit med sig $\mathrm{i}$ sina väskor och packlårar. Samtidigt rymmer denna populära utställning en tydligt kritisk udd. Ambitionen är att visa hur de insamlade föremålen också använts för att göra skillnad mellan, å ena sidan, primitiva och avlägsna Andra; och, å andra sidan, upplysta, rationella och normala svenskar.

Världen i kappsäcken är därmed ett bra exempel på en utställning som rymmer ett sådant riktat seende som efterlyses i antologin Det bekönade museet (2005, red. Meurling \& Aronsson). I denna antologi diskuteras i ett antal artiklar vad som blir synligt och dolt på museer och i utställningar. Det författarna betonar är blickens betydelse för den museala representationen: för vad som blir utställt och betraktat samt, i förlängningen, även potentiellt tillgängligt för besökarnas egna reflektioner (jfr. Alpers 1991, Bennett 1995). I Värl- den i kappsäcken möts besökaren av utställarnas ambition att göra vissa förhållanden synliga. Föremål och texter används för att kommentera och problematisera både vad det är som ställs ut och varför det alls finns på museet (Wagner 2002, Östberg 2002 ). Genom att göra detta kan utställarna peka på de flerskiktade historiska sammanhang där både museet och samlingarna uppstått. Utställningens grundläggande berättelse är beskrivningen av hur etnocentriska, koloniala och postkoloniala maktförhållanden utgör samlingarnas och det museala samlandets själva förutsättning.

Att göra en genusgranskning av ett museum som Etnografiska är i grund och botten samma sak som sker i en utställning som Världen i kappsäcken. Det handlar om att anlägga en eftertänksam blick på den museala verksamheten. Att fråga sig vad det är som, å ena sidan, efterfrågas, samlas in, arkiveras och visas upp - dvs vad som lyfts fram och betonas - respektive vad som, å andra sidan, har en benägenhet att återkommande hamna utanför blickfältet (Grahn 2000). Det gäller kort sagt att finna ut vad det är för ett museum som besökarna möter när de vandrar runt i utställningarna; för att därifrån gå vidare med den mer utmanande frågan om hur museet också fungerar som en apparat för särskilda framställningar och specifika seenden (jfr Brenna 2002, Gustafsson Reinius 2008, Eriksen 2009). I bägge fallen är det meningsfullheten, kunskapsproduktionen och de museala vetandeformerna som sätts i förgrunden.

\section{ATT TÄNKA KÖN}

Vid genusgranskningen av Etnografiska museet använde vi oss av ett lika riktat seende som $\mathrm{i}$ Världen i kappsäcken. Men eftersom linsen var en annan blev det något annat som ham- 
nade $\mathrm{i}$ förgrunden - och detta något är det som ryms i begreppet genus. Men vad är då egentligen genus? Svaret kan göras mycket kort och har i själva verket redan antytts. Med genus menar vi helt enkelt föreställningar och idéer om manligt och kvinnligt. I vår användning refererar därmed termen kön till biologi och anatomi, medan genus handlar om alla de mer eller mindre långtgående idéer som häftar vid det biologiska könet. Kön och genus är alltså inte samma sak. Precis som att genus heller inte är liktydigt med jämställdhet (ett annat vanligt missförstånd). Samtidigt kan tilläggas att en stor del av den akademiska diskussionen på senare år har gått mot att betona att såväl kön som genus är förankrat i ett kontinuerligt görande och alltså inte något vare sig biologiskt eller kulturellt givet (Butler 1990, 1993, jfr. Rosenberg 2002). Frågan om hur våra kroppar ska tolkas är i en mening alltid en öppen fråga: något som förändras över tid och rum, och något som sker mot bakgrund av en historisk och kulturell kontext (jfr. Laqueur 1994).

Detta är också förklaringen till all den variation som uppträder när man tittar lite närmare på människors föreställningar om vad som är manliga respektive kvinnliga beteenden, karaktärsdrag eller förmågor. Som alla vet finns det gott om föreställningar om vad det är som inbördes förenar gruppen av män respektive kvinnor, samtidigt som det också skiljer dem från det andra könet. Men påfallande ofta skiljer sig dessa förväntningar åt om man ser till olika folk eller samma folk över tid. De kan variera över århundradena. En man som i dagens Sverige gärna pryder sig i pastellfärgat siden och dito sammetstyger riskerar att få såväl sin manlighet som sitt heterosexuella begär ifrågasatt: så icke i finare kretsar på 1700-talet. De kan variera socialt, mellan exempelvis oli- ka samhällsklasser. En borgerlig kvinna under det sena 1800-talet betraktades som skör och svag, medan en bondhustru eller arbeterska under samma tid blev en duglig kvinna genom att vara arbetsam och stark. Och det kan variera geografiskt; antropologi och andra liknande ämnen brukar i förekommande fall dräneras på pedagogiska exempel (Kulick 1987, Gemzöe 2003: 79ff.).

På det här viset har genus många likheter med begreppet könsroll som var vanligt på 1970- och 80-talet. Men när könsroller fokuserade på övertagande av en redan färdig uppsättning förväntningar om ett visst könsspecifikt uppträdande, så betonar genusperspektivet att föreställningar om kön är något som går långt utöver den enskilda individen. Genus implicerar därför mer än vad kvinnor och män förväntas göra och hur de förväntas uppträda. Arbetsdelning, ekonomi, fördelning av makt, status och ansvar, sexualitet och reproduktion, kosmologier och människors symbolvärldar - allt detta är helt enkelt svårt att förstå om man inte tar hänsyn till att samtliga dessa fenomen också är sammanvävda med en uppsättning kulturbundna föreställningar om manligt och kvinnligt.

Vill vi att våra museer ska vara något utöver platser för upplevelser och rent estetiska intryck blir det närmast absurt att inte uppmärksamma en så central ordnande princip som kön eller genus. Helt enkelt av det skälet att det vore att avhända sig möjligheten av en fördjupad förståelse av de föremål, sammanhang och berättelser som vi förknippar med museisamlingar.

\section{FRÅN KÖN TILL GENUS - OCH TILLBAKA}

Efter att ha slagits av den märkliga upplevelsen av att först ha vandrat genom ett antal 
Fig. 1. Det stora collage som visades på en egen vägg längst in i den gamla indianutställningen.

Foto: Rose-Marie Westling, Etnografiska museet.

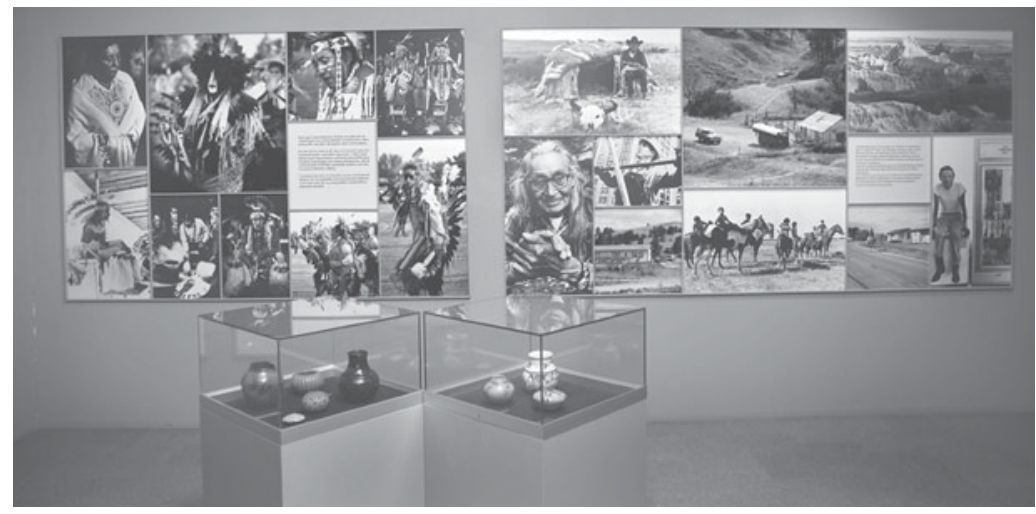

utmärkta och välbalanserade utställningar, bara för att ett par timmar senare betrakta samma utställningar som iscensättningar med höggradig manlig bias, bestämde vi oss för att börja räkna. Det som tog vid var fokuserade observationer avseende vad och vilka det var som visades och kommenterades på museet. $\mathrm{Vi}$ tittade in i montrar och antecknade föremål och bilder; vi läste på skyltar och jämförde olika texter för att få reda på vad och hur man skrev om vem (jfr. Hirdman 1994, Lundgren 1993, 1994).

Det är viktigt att understryka att detta räknande inte är en genusanalys, men att det kan vara ett praktiskt första steg för att kunna genomföra en sådan längre fram. Räknandet handlar om andelen män respektive kvinnor (eller rättare sagt gällde vårt räknande hur många föremål som kunde hänföras till en kvinnlig eller manlig domän, respektive hur många bilder som föreställde antingen kvinnor eller män). Vitsen med detta är att för den som vet andelen kvinnor och män i en utställning är det lättare att ställa andra och mer analytiskt drivna frågor. Finns det ett mönster i dessa presentationer? Är till exempel "indianen” oftare en man än en kvinna? Vem är den obestämda människa som visas upp genom olika föremål och kommenteras på skyltarna? Kort sagt, hur är kön synligt eller osynligt inlagrat i de olika utställningarna?

För tydlighetens skull är det kanske också bäst att tillägga att en genusmedveten utställning inte alls behöver ha en likvärdig representation mellan kvinnor och män. Många gånger kan det tvärtom vara bättre att till exempel spegla strikt manliga domäner, att lyfta fram och kommentera sådant som män, eller huvudsakligen män, har gjort. Dock bör det i så fall framgå att det är detta som sker. Det bör vara klart angivet att nu är det män och inte människor som visas och diskuteras, vilket också är förklaringen till att kvinnor eller flickor inte finns med i samma utsträckning. Men när vi granskade utställningarna på Etnografiska museet saknades helt och hållet förtydliganden av det slaget. Texterna innehöll istället oftast skrivningar som presenterade folk, regioner och samhällen i (köns)neutrala och allmänna termer. Det dominerande tilltalet var ett där man begagnade sig av breda och övergripande etiketter som "indianer", "jägarfolk, "de arktiska folken", "nomader", "aboriginer" osv. 
När vi på ett seminarium med personalen på Etnografiska museet presenterade våra preliminära intryck och slutsatser blev det snart tydligt att intentionerna att visa mer av kvinnorna hade funnits under arbetet med att färdigställa flera av museets utställningar. Men av olika skäl hade det sedan inte riktigt blivit så när det hela stod färdigt. Just de idéerna hade fallit bort under resans gång eller också hade kvinnorna under en tid varit fler i någon del av utställningen som nu är borta.

Kanske, fördes det också fram under diskussionen, handlar det även om att de befintliga samlingarna inte är lämpade för att lyfta fram kvinnor och kvinnliga sysslor. De äldre samlarna och resenärerna hade ofta blicken riktat mot männens vapen och andra "manligt kodade" föremål knuta till prestige, prakt och kult. Manliga samlare av både äldre och nyare datum, fortsatte detta argument, har ofta också verkat i kulturella miljöer där de i praktiken bara haft tillträde till de domäner som befolkats av andra män. Den forskare som i etnografiskt uppsåt närmar sig kvinnorna skulle alltså lätt kunna uppfattas som någon med ett både misstänkt och otillbörligt uppträdande.

Poängen är nu inte att de ovan nämnda förklaringarna skulle vara fel eller bör uppfattas som undanflykter. Säkert har det hela tiden funnits rimliga och relevanta skäl till att de idéer som inbegrep kvinnorna inte lät sig realiseras. Men lika tydligt är att det inte funnits några lika starka skäl som kunnat tjäna som en garant för att kvinnorna inte försvann, vilket de därför till stor del gjorde.

När vi under seminariet hävdade att kvinnornas representation i utställningarna var mycket mindre än männens verkade de flesta hålla med i sak. Man tycktes dessutom ge oss

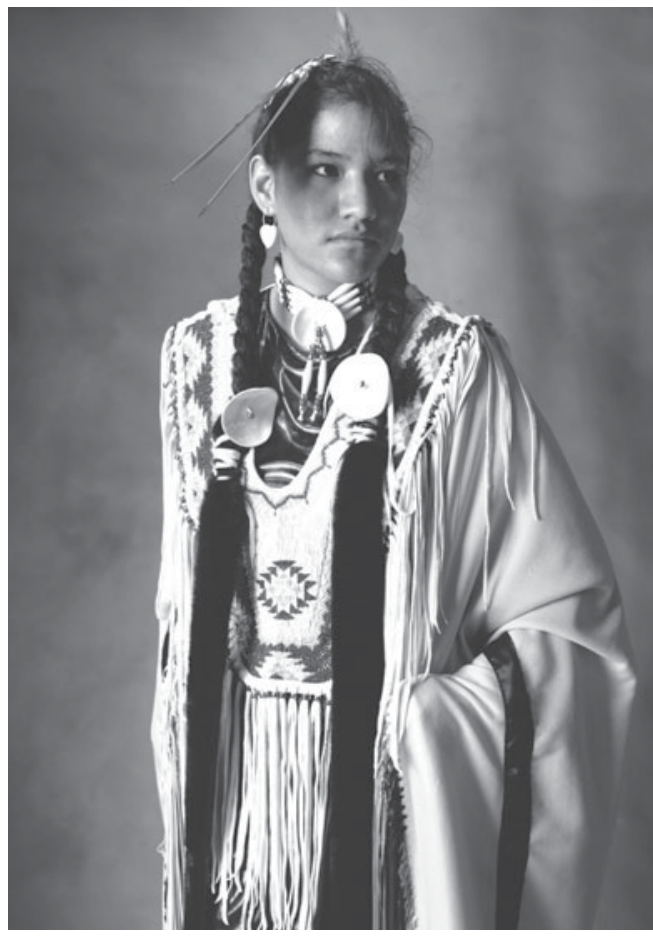

Fig. 2. Det stora kvinnoporträtt som visas vid huvudentrén till den nya indianutställningen. Bildtexten lyder: "Lonée Roy, og oglala-lakota frän Pine Ridge fotograferad i Stockholm under en turné med Lakota Dance Company, då hon dansade Fancy Shawl Dance. Foto: Tony Sandin 1992."

rätt i att kvinnorna borde få mer plats i utställningarna än vad som nu sker, liksom att det verkligen fanns ett antal formuleringar i de då aktuella utställningarna som på ett olyckligt sätt generaliserade mannen till människa, och omvänt gjorde människan till man.

Ändå var det ett faktum att kvinnornas kunskaper, föremål och sysslor många gånger inte riktigt kom fram i museets utställningar. För att ta ett konkret exempel, vad hände egentligen med kvinnornas del av den vardag som är en förutsättning för ett fungerande jä- 
garsamhälle? Vårt intryck var att det både visades och ordades väldigt lite om vad som hände med det fällda bytet. Och ändå kan man knappast tänka sig ett jägarfolk utan en samtidig beredning av köttet, hudarna, dunet eller pälsarna. Lika lite som jägaren själv låter sig tänkas utan sina kläder eller kajaken utan det skinn som är spänt över spanten. De processer, handgrepp och kompetenser varigenom bytesdjuren förädlas till något annat än blott och bart döda djur är också en del av dessa samhällen. Ändå kunde vi konstatera att montrarna i flera fall bågnade av redskap som hänförde sig till männens jakt och fisketurer. Kontrasten var stor om man jämförde med hur de kvinnliga domäner som exempelvis handlade om tillverkningen av jägarens kläder och kajakens skinn sällan eller aldrig blev huvudnumret i det drama som museet lade sig vinn om att visa och gestalta.

\section{KATEGORIER OCH (BORT)SEENDEN}

Därmed är vi tillbaka till de frånvarande kvinnorna och den meningsfullhet som omger deras frånvaro. Trots att utställningarna i stora stycken vilade på en tydlig manlig övervikt fanns det uppenbarligen något i både presentation och komposition som gjorde att blicken hade svårt att riktigt få fäste på detta förhållande. Montrar och föremål knöts ihop av en ordning som framstod som så naturlig att den effektivt motade bort andra tolkningar (jfr. Haraway 1989, Samuelsson 2008: 163ff.).

Den fråga vi måste besvara är alltså vad det är som bidrar till att osynliggöra kvinnornas relativa osynlighet. Till vår hjälp för att demaskera detta illusoriska trick har vi satt samman några arbetshypoteser. Vi antar, inledningsvis, att det på museet finns två logiker eller invanda tankespår som i hög grad bidrar till den uppkomna situationen. Den första av våra hypoteser kallar vi för (1) principen om manliga huvudsysslor och kvinnliga komplement; den andra för (2) principen om det återkommande valet att välja något annat än kvinnor.

Den första av dessa hypoteser har en förhistoria. Vid en nu nästan tjugo år gammal genomgång av Samdokmuseernas rapporter konstaterades en tydlig snedvridning i museernas dokumentära ansatser vad gällde arbetslivsstudier (Bäckman 1995). Inte nog med att en överväldigande majoritet av undersökningarna riktades mot näringar där manliga utövare var i majoritet, utan även om det fanns kvinnor i dessa näringar blev de sällan uppmärksammade mer än i förbigående. Ett kort exempel från en av rapporterna som handlar om samtida jordbruk kan illustrera hur kvinnorna sällan förväntades vara en del av de sammanhang som skulle undersökas.

Det är heller inte jordbruket i sig vi i första hand vill komma åt. Snarare är det människan bakom verket, den skaraborgske bonden, hans villkor och hans sätt att förhålla sig till sitt yrke och det samhälle som i mycket formar reglerna för hans handlande [vår kursiv].

Genomgången av ett drygt femtiotal liknande arbetsplatsrapporter visade att skulle man dokumentera något sådant som ett jordbruk eller ett sågverk så gick man till åkern, skördetröskan, ladugården, sågen eller brädgården; inte till gårdens kök eller sågverkets kontor - där kvinnorna mer ofta höll till. Det som i hög grad uteslöt kvinnorna och osynliggjorde deras faktiska närvaro och insatser var alltså den uppsättning kategorier som rapportförfattaren hade med sig ut i fält. Det underförstådda antagandet var att en bondgård inte gärna kan dokumenteras med utgångspunkt i köket eller 
90 tvättstugan; lika lite som det verkade vettigt att börja en dokumentation av ett sågverk med ett besök i administrationen. Att sedan gården inte kan tänkas utan sin reproducerande del, eller sågverket utan sin administrativa, hörde liksom inte dit. Själva självklarheten i dessa utgångspunkter - den naturaliserade kopplingen mellan bonden och hans jordbruk, liksom mellan sågverket och den manlige sågverksarbetaren - blev det som sorterade bort kvinnorna från det som skulle dokumenteras och minnas åt eftervärlden. Och att redan begreppet arbetsplatsstudier i flertalet av dessa rapporter verkade implicera ett intresse bort från kvinnodominerande arbeten och till mansdominerade gjorde inte saken bättre.

Naturligtvis avspeglar inte en undersökning med nästan två decennier på nacken det ambitiösa arbete kring urval, representation och kategorisering som i hög grad präglat Samdoks insamlingar och verksamhet efter det att rapporten skrevs. Avsikten med att återvända till de äldre rapporterna är istället att dessa hjälper oss att få syn på den typ av logik som gör det både möjligt och skenbart förnuftigt att utesluta den kvinnliga närvaron från en viss verksamhet. Bondgården associerades med den manliga bonden vars göranden sedan uppfattades som gårdens egentliga huvudsysslor. Kvinnorna och deras uppgifter blev på motsvarande sätt kategoriserade som, i bästa fall, ett mindre betydelsefullt komplement till gården/bonden eller sågverket/sågverksarbetaren.

$\mathrm{Nu}$ ska det erkännas att vid tiden för vår genusgranskning av Etnografiska museet var det rätt ont om både bönder med skördetröskor och sågverksarbetare i museisalarna. Däremot använde man sig flitigt av andra och liknande summerande etiketter. Under rubriken "Ursprungsfolken i norr", stod till exem- pel i en av utställningarna följande text att läsa:

De ursprungliga folken i Antarktis är av tradition jägare, fiskare och/eller renskötande nomader. Deras naturahushållning ryms inom tre ekologiska sammanhang; havet, tundran och skogen. Renskötseln började i Europa och Asien under 1500- och 1600-talen, i Kanada och Alaska först kring sekelskiftet 1900.

I en annan monter i samma utställning låter man en skildring av valfångst från kajak växla mellan bild och text. "Narvalsjakt i nordvästgrönland" får därigenom en lika påtagligt dramatisk som exklusivt manlig inramning:

Den traditionella kajaken är fortfarande den mest effektiva vid narvalsjakt. Däremot törs knappt någon längre jaga valross från kajak. Det gäller att komma på mindre än tio meters håll för att kunna träffa med kastharpunen. Ett enda bomkast gör att valarna försvinner.

Infälld bild på man i kajak med isberg i fonden Plötsligt dyker tre valar upp. Alldeles framför Mamarut Kristiansen och med riktning rakt mot honom. I samma ögonblick är harpunen i luften och en sekund senare når den sitt mål.

Infälld bild på harpunerad val och två män som tar hand om fängsten hängandes ut frän en mindre motorbait.

Ett stort plask indikerar fullträff. Det stora flötet, ett uppblåst sälskinn, rusar snabbt iväg över vattnet och försvinner ner i djupet. På stranden utbryter febril aktivitet. Motorbåtar startar och alla ger sig iväg mot jägaren och bytet.

Gång efter annan visade det sig att museets sätt att närma sig och presentera olika folkslag och kulturer vanligen utgick från de aktiviteter som den manliga delen av befolkningen hade för händer. Männen stod för den egentli- 


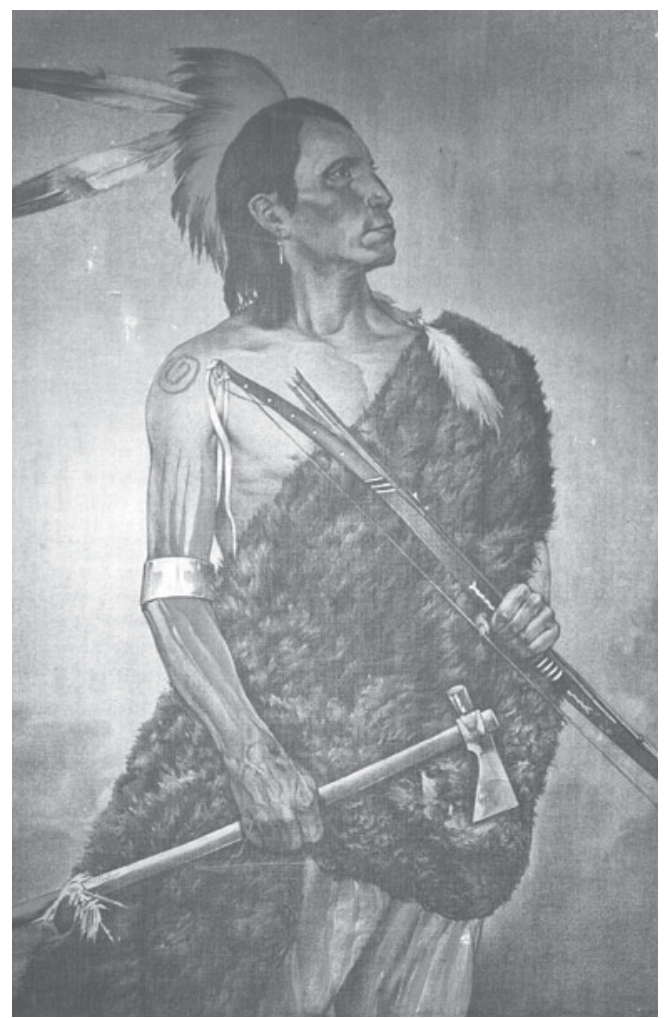

Fig. 3. Bilden av siouxindianen Good Eagle är daterad 1901 och baserad på ett äldre fotografi taget frän fotoateljén F.A. Rinehart i USA. Foto: Rose-Marie Westling, Etnografiska museet.

ga och definierande verksamheten - kvinnornas bidrag var ett komplement. Och detta trots att den spektakulära jakten egentligen bara är en del i den process där bytesdjuret av både män och kvinnor omvandlas till nödvändiga eller efterfrågade produkter.

\section{VAD MUSEER VÄLJER ATT VÄLJA}

Under det att en utställning förbereds och så småningom ges en färdig form sker hela tiden en mängd val som vid varje tillfälle ter sig rationella och förnuftiga. De inblandade väljer något av flera tänkbara alternativ; tar ställning för enskilda föremål på bekostnad av några andra, premierar ett enskilt textförslag eller visst fotografi, bestämmer sig för en eller annan konkret visuell och estetisk lösning på det problem som är för handen.

Vad som osynliggörs av detta samlade förnuft är det systematiska draget i de bortval som samtidigt blir följden. Genom att inte lägga samman de många, små valen blir det aldrig tydligt vad de har gemensamt; nämligen att de i praktiken formar ett närmast regelmässigt underskott av faktiska kvinnor likaväl som av kvinnliga föremål och sysslor. Den kvinnliga frånvaron på museerna döljs av sin egen fragmentarisering. Vid vart och ett av de enskilda besluten framstår det av ett eller annat skäl som klokare att diskutera männen som aktörer eller att visa upp manligt kodade föremål. Varje bortväljande av kvinnorna verkar oantastligt och fullkomligt legitimt, men lagda tillsammans blir resultatet av de många små besluten ändå fullkomligt orimligt.

Det som är viktigt att förstå här är just sambandet mellan museal praktik och kvinnlig frånvaro. Vanan att tänka i färdiga och inarbetade kategorier där kvinnor och kvinnliga domäner eller sysslor inte riktigt får plats bidrar till intrycket av att man från museets sida inte väljer bort kvinnor, utan att man vid varje enskilt tillfälle väljer något annat. Bortväljandet av kvinnorna försvinner ur sikte och därför kan heller ingen vare sig se eller ta ansvar för den systematik som tenderar att upprepa sig tvärs genom de många valen. Det faktum att man varje gång väljer något annat skymmer det lika tydliga faktum att man så gott som alltid väljer bort samma sak. 
92 Följden av denna systematik blir precis det förhållande som vid tiden för vår granskning genomsyrade utställningarna på Etnografiska museet: att det med få undantag blev något annat som fick företräde framför den lösning som inbegrep eller kanske till och med utgick från kvinnan eller flickan. Därför ska man heller inte bli förvånad över den mängd av kvinnliga tillägg - montrarnas komplement och små inskjutna bisatser - som präglar en stor del av dagens utställningar på våra museer. Det är nämligen vad som återstår att göra när de idéer, upplägg och gestaltningar som utgick från kvinnor och flickor aldrig blev mer än goda intentioner.

Ibland blir denna obalans nästan övertydlig. Inte ens när kvinnorna eller flickorna bereds plats verkar man lägga märke till att det sker på andra villkor. Också här har vi ett belysande exempel. När man från museets sida vid ett tillfälle berättar om ritualer i samband med vuxenblivande gör man det med hjälp av två initiationsriter från Amazonas. Det första citatet nedan är den kompletta text som kommenterar "Flickornas initiering". Det andra visar hur man skildrar pojkarnas motsvarande inlemmande i vuxenvärlden, denna gång under rubriken "Myrprovet". De båda texterna hänger i direkt anslutning till varandra.

\section{Citat 1.}

En flickas första menstruation är en viktig händelse och ett tydligt tecken på övergången till vuxenlivet. Hon isoleras då från de andra i byn för att genomgå reningsritualer.

\section{Citat 2.}

För en ung pojke i Amazonas kan övergången in i vuxenlivet innebära att uthärda getingstick eller bitande myror.

Myrorna får ligga i vatten över natten så att de blir slöa. Sedan fångas de in med en särskild handske och placeras på pojkens kropp.

Alla i byn samlas för att delta i ceremonin. Efter en stunds plåga tas myrorna bort. Men proceduren kan upprepas upp till sju gånger.

Myrornas bett anses vara stärkande och jägare genomgår myrprovet flera gånger för att skaffa sig extra styrka

Alldeles som när det tidigare gällde valjakten är det tydligt hur pojkarnas initiering genom textens utformning ramas in, dramatiseras och presenteras som ett äventyr och en prestation. Flickornas vuxenblivande blir avklarat på betydligt färre och dessutom mer intetsägande rader. Men skillnaden mellan de två texternas omfång och karaktär har uppenbarligen aldrig uppmärksammats eller också inte upplevts som ett problem.

\section{SVARTA LÅDOR}

Som två sidor av samma mynt gör de två arbetande principer vi pekat på - den manliga huvudsysslans företräde och det återkommande valet att välja något annat än kvinnor - att kvinnornas relativa frånvaro uppfattas som följden av enskilda, tillfälliga och praktiskt betingade beslut. Det verkar helt enkelt förnuftigt att beskriva olika slags folk, kulturer och samhällen som just jägare, nomader, indianer, valfångare eller renskötare. För det är ju ändå det som de är. Men likväl är effekten av såväl de summerande kategoriseringarna som de oavsiktliga bortvalen synnerligen påtaglig.

För att bättre förstå de processer som är verksamma inom museernas fyra väggar kan vi vända oss till Bruno Latour och Michel Callon. De båda vetenskapssociologerna hävdar att avsaknaden av en levande diskussion om förekomsten av vissa inarbetade rutiner, vanor och institutionella praktiker gör att dessa förr 
eller senare hamnar i verksamheternas svarta lador (Latour \& Callon 1981: 19). Rutiner, praxis och olika materiella omständigheter har då uppnått en sådan status av självklarhet att de bokstavligt talat försvunnit ur sikte; och just genom att vara undandragna från medveten reflektion kan de motståndslöst sprida sina verkningar inom institutionen (jfr. Gustafsson Reinius 2008, se även Knuts 2006: 46). Kvinnornas frånvaro i både montrar och utställningar har med tiden fått just detta drag av oreflekterad självklarhet över sig. I samma stund som deras relativa osynlighet i utställningarna framstår som inte bara legitim utan också förnuftig blir deras frånvaro även osynlig.

Det finns en slående likhet mellan museets dubbla osynliggörande (av dels kvinnorna och dels deras frånvaro) och hur bondelivet i den tidigare omnämnda Samdok-rapporten kunde reduceras till endast den manliga "bondens" göranden. På det här sättet riskerar några få centrala kategorier och tankefigurer att styra och ställa med verksamheten i stort. Inte vid något av de inblandade museerna fanns en önskan om att kvinnorna skulle synas mindre än männen och alla var lika förvånade över att så skett. Men när man inte hela tiden bråkar med sina egna svarta lådor - och heller inte får vare sig fortbildning eller resurser att göra detta - är det lätt hänt att kvinnornas aktiviteter försvinner ur sikte. Och för det mesta sker det alltså utan att någon ens märker hur det egentligen gick till. De människor och erfarenheter som beskrivs blir i första hand till berättelserna om vad männen gör och gjorde på dessa platser.

\section{ATt GÖRA GENUS}

Hitintills har vi varit mer kritiska än konstruktiva. Men hur gör man när man bråkar med svarta lådor? Hur åstadkommer man utställningar som är mer genusmedvetna och ibland även utmanar besökarnas egna stereotyper och kategorier? Ja, rent allmänt finns det goda skäl att vara vaksam mot det könsneutrala språk som ofta förekommer i museisammanhang. Som tidigare framhållits är det utmärkande för en genusmedveten utställning att den är tydlig med sina egna utgångspunkter. Det är därför som det könsneutrala språket i många utställningstexter blir så förledande. Som benämningar utgår inte "jägaren", "fiskaren" eller "bonden" i sig själva från kön, men när begreppen används i utställningssammanhang är det nästan alltid i relation till en manlig erfarenhetsvärld. Här handlar det alltså om framställningar som skildrar en manlig värld utan att tala om det för besökarna. Men ensidigheten i urvalet syns inte i språket eftersom de valda begreppen är just könsneutrala. ${ }^{4}$

Av detta följer att ett generellt råd vid en genusgranskning av en utställning är att beköna även de texter, bilder och föremål som inte uttryckligen talar om kvinnor eller män (vem avses med formuleringen, vilka föreställer bilden, vem brukade eller brukar föremålet). För gör man inte detta är det svårt att upptäcka hur stor del av utställningen som handlar om endast det ena könets skapande, görande, villkor osv. Bekönandet kan göras visavi redan färdiga utställningar, men kan också vara ett led $\mathrm{i}$ arbetsprocessen när det gäller att ta fram en ny eller reviderad utställning. Ofta är det först härigenom som vi får en nödvändig distans till våra egna vanor och ovanor. Vilka föremål har vi plockat fram från magasinen och hur samspelar dessa med de föreslagna bilderna och texterna? Vad "fattas" i de egna samlingarna och kan luckorna kanske användas för att belysa eller kommentera äldre insamlingsideal? Var någonstans i utställningen är 
94 det lämpligt att skapa plats för tankepauser och reflektion över utställningens och museets bärande berättelser?

I det följande ska vi ta tre bilder från utställningen "Nordamerikas indianer" på Etnografiska museet till utgångspunkt för att beskriva hur det med små medel går att åstadkomma märkbara skillnader. Den första bilden [bild 1] står för ett mindre lyckat exempel och är hämtad från den gamla indianutställningen. Det är ett stort collage - placerat längst in i utställningen där den täckte så gott som en hel vägg - ägnat att understryka det faktum att indianer inte bara är något som hör prärien och det förflutna till. Tvärtom, ville man från museets sida framhålla, finns indianer även idag; de har bilar, bor i hus, jobbar som byggnadsarbetare och är på olika sätt en del av det moderna samhället. Problemet var bara att av det knappa trettiotal personer som visades var det bara en, eller möjligen två, som inte var män. Vägledda av viljan att förklara för besökarna att Nordamerikas indianer är en del av det samtida samhället bekräftade man från museets sida således, utan att märka det, en annan och lika osann bild av "indianen". För genom att nästan helt utesluta kvinnorna från collaget förstärktes den segdragna stereotyp som knyter ihop föreställningen om "indianen" med ryttaren, spejaren, krigaren, jägaren osv, dvs indianen som man.

Med collaget i färskt minne stod det klart att den nya indianutställningen bland annat måste inskärpa det till synes självklara: indianer är lika ofta kvinnor som män. I utställningen görs detta med hjälp av ett strategiskt samspel mellan (urvalet av) föremål, bild och text. Men det sker också genom användandet och placeringen av några särskilt betydelsefulla bilder. Den första och viktigaste av dessa är det stort uppslagna svartvita fotografi [bild 2] som besökaren möter redan vid ingången till utställningen. Bilden föreställer en kvinna klädd i den typ av traditionella kläder som används vid en så kallad pow wow, men med ett tydligt modernt snitt. Liksom i collaget möts i fotografiet alltså både nutid och dåtid, samtidigt som "indianen" denna gång är en ung kvinna.

Den sista av våra tre bilder [bild 3], en avbild av ett porträtt från senare hälften av 1800-talet, närmar sig frågan om den kvinnliga representationen från ett annat håll. Här blir metoden inte att byta ut eller att ersätta, utan att öka graden av kritisk distans. För de flesta av oss är motivet på denna tredje bild säkert välbekant. Porträttet föreställer en man med kraftfullt yttre och skarp profil vars allvarliga blick förlorar sig i fjärran. Örnfjädrar, pilbåge och tomahawk kompletterar den gängse uppfattningen om den typiske indianen. Men genom att lägga till ett par rader med text på porträttet förvandlas detta till sin egen metakommentar.

Vem är mannen på bilden? En stor jägare som varit med om forna buffeljakter? En krigare som utan fruktan sett sina fiender i vitögat? Eller en vis ålderman, en gestalt nära Moder Jord?

Är det inte så att vi gärna läser in våra egna föreställningar i porträttet? Är det inte typiskt att "indianen” är en man, att det är just jägaren, krigaren, vältalaren som vi uppmärksammar? Kvinnorna försvinner lätt ur sikte.

Tillägget omvandlar den befintliga bilden till en reflexionspunkt vars syfte är att uppmärksamma besökaren på det komplex av framställningar som upprätthåller kopplingen mellan "indianen" och mannen. Med dessa enkla medel har den traditionella bilden av indianen tilldelats en subversiv uppgift i relation till etablerade föreställningar och stereotyper. 


\section{DET SVÅRA MED GENUS}

Huvudsyftet med artikeln är att diskutera några av de museala praktiker som gör att kvinnorna inte ges plats i utställningarna och som dessutom bidrar till att denna frånvaro aldrig riktigt märks. De omständigheter vi så här långt har pekat på har det gemensamt att de vilar på en naturalisering av tidigare val och urval. Att kvinnor är osynliga blir något som inte syns. Osynliggörandet blir osynligt.

Till det som gör det svårt med genus generellt på museer kan emellertid också räknas en påfallande idékonkurrens vad gäller utställningarnas innehåll och utförande. Genus är en analytisk ingång - ett perspektiv - som avser att visa hur kulturbundna föreställningar om könsskillnader i hög grad kritar upp gränserna för vårt sociala vara. Därmed konkurrerar det med andra perspektiv och utställningsidéer som vilar på lika tydliga upplägg och visioner. Världen i kappsäcken kan återigen anföras som ett bra exempel. Här finns ett angeläget och färdigpaketerat budskap: den kritiska vidräkningen med kolonialism och svensk etnocentrism. Sant eller ej kan ett genusperspektiv uppfattas som ännu ett raster att lägga över redan noga utvalda föremål och berättelser. Kanske minskar införandet av ännu ett centralt perspektiv slagkraften hos de tankar och genomföranden som utgör utställningens bärande tema. Invändningarna är förmodligen välkända för alla som varit verksamma i utställningsproduktion: det finns inte riktigt plats för flera maktordningar; besökarna tål inte alltför mycket komplexitet; det blir för mycket text. Att genus får stryka på foten kan alltså ses som ett uttryck för omsorgen om både besökarna och den enskilda utställningens ursprungliga idé.

Men varför ser vi i så fall inte fler utställ- ningar där genusperspektivet tillåts vara den dominerande ingången till de föremål och berättelser som får ta plats? Är det för att det inom muserna finns en uppfattning om att perspektivet är för brett och därmed svårt att fokusera i en utställning; att det är för gammalt och redan passé, för tråkigt, för deprimerande? Eller går de interna resonemangen tvärtom ut på det rakt motsatta: att perspektivet är för smalt och därmed saknar allmänintresse; att det för nytt och utmanande, att tiden kanske inte är mogen? Dessa frågor får vi lämna obesvarade medvetna om att vårt resonemang är långt ifrån fullständigt. De slutsatser vi redovisat räcker inte för att förklara varför genus så sällan uppfattas som en relevant ingång till moderna och uppdaterade utställningar. Här finns alltså anledning att fortsätta fundera: vilka argument är det som formuleras inom museernas väggar? Vad fortsätter att ticka i lådan?

En omständighet som kan antas bidra till den rådande situationen tar vi oss dock friheten att peka på. På muserna sätts ofta det spektakulära i högsätet. Det är det dramatiska, ovanliga och färgstarka som ljussätts och kommenteras. Museer lockar besökare genom att skylta med liv, nerv och märg. Kom och se! Låt er förundras! Till och med när det är vardagen som ska bevakas trängs det grå och trista ofta ut av det vackra eller farliga. Här menar vi att det finns en risk för att kvinnors liv och föremål har svårare att hamna i ljuskäglan. Inte för att deras liv skulle sakna vare sig färgstarka uttryck eller dramatik, utan för att det kräver att man aktivt väljer att öppna de svarta lådorna och ger sig i kast med de många museala självklarheter som dväljs i dessa. Det kan kort sagt bli både svårare och bökigare att hitta fram till rätt föremål om de ska hämtas från kvinnligt kodade domäner. Alldeles bort- 
sett från att kraven på att göra estetiskt tilltalande utställningar riskerar att hamna i konflikt med mer idéburna utställningar. För när de estetiska hänsynen blir dominerande i utställningarna blir det också bekymmersamt med idéer och resonemang som kräver längre texter och svårare ord. Estetiken vill gärna vara vacker och den vill gärna tala för sig själv. Detta kan vara svårt att kombinera med mer reflekterande syften.

Naturligtvis är det en truism att utställningar är en fråga om urval och bortval. Men mer än många andra skapande verksamheter präglas utställningsarbetet av att det sker mot bakgrund av ett ständigt kompromissande mellan olika intressenter och yrkesroller. I praktiken innebär detta att olika professionella synsätt riskerar att hamna i konflikt med varandra. Formgivarens ideala utställning överensstämmer inte alltid med den ämnesansvarigas och producenten kan i sin tur sikta mot en tredje vision. Har man då dessutom ett utställningsmanus skrivet av ännu en person, inom eller utanför museet, är det upplagt för kattrakande kring vars och ens ursprungliga tankar och idéer. Våra egna erfarenheter på området talar därför för vikten av att museiledningen tydligt markerar genusperspektivets betydelse för den färdiga utställningen.

En sådan markering från ledningen är ingen garanti för ett lyckat resultat. Men på grund av de många tysta självklarheter som ligger inkapslade i museernas svarta lådor blir museiledningens uttalade stöd i det här fallet extra viktigt. Genom att tydligt markera att "nu gör vi en genusmedveten utställning" minskas risken för att fördelningen mellan huvudsyssla och komplement ser ut som den brukar; eller att bortväljandet återigen ensidigt drabbar kvinnor och kvinnliga föremål. Däremot finns det ingenting i en sådan mar- kering som säger att den aktuella utställningen också kommer att behandla även frågor om makt, inflytande och hierarki. För att detta ska ske krävs en mer ingående diskussion om vad genus på museum är eller kan vara.

\section{UTMANA OCH REFLEKTERA}

När vi nu strax avrundar granskningen av vår egen granskning fattas bara några korta och avslutande kommentarer. Först och främst vill vi framhålla att även om de empiriska exemplen är hämtade från Etnografiska museet har detta museum knappast fler eller större problem än andra. Tvärtom är vi övertygade om att just här finns det ovanligt goda förutsättningar att utmana och problematisera flera rådande föreställningar om kvinnlighet och manlighet. Tack vare personalens ämnesmässiga kompetens och de rika samlingarna ruvar Etnografiska museet på en veritabel skatt av spännande och vardagliga objekt: av kunskaper som ännu inte getts plats, av historier och öden som återstår att berättas.

Sedan är det också möjligt att utifrån vår artikel dra slutsatsen att det finns åtminstone tre konkreta utmaningar när det gäller museer, samlingar och genus. För det första handlar det från museernas sida om behovet av att identifiera sina egna svarta lådor, dvs det vetenskapliga och vanemässiga maskineri som lett fram till dagens situation. För det andra gäller det att i sina kistor och kappsäckar hitta just de föremål, scenarier och berättelser som skulle kunna användas för att bryta upp dessa invanda boxar, utan att för den saken skull välta allt annat över ända. Vilket leder vidare till den tredje och största utmaningen, nämligen att göra utställningar som visar att kvinnorna och deras arbete aldrig varit bara ett 
samhälleligt komplement utan tvärtom en förutsättning för dessa samhällens fortbestånd och utveckling.

Efter detta återstår bara ett sista konstaterande. Vad vårt resonemang till sist kokar ned till är att en genusgranskning egentligen inte alls handlar om vare sig antal, omfång eller mängd. Det som motiverar en sådan undersökning är istället behovet av att föra en kontinuerlig diskussion om hur olika museala iscensättningar av kvinnor och män, av manlighet(er) och kvinnlighet(er), bidrar till att forma och begränsa olika subjektspositioner. Trots allt har det kulturellt organiserade görandet av män/manligt och kvinnor/kvinnligt alltid utgjort en väsentlig del av vår förståelse av oss själva som individer och sociala varelser.

Mot en sådan bakgrund framstår två konkreta frågor som särskilt viktiga att inte tappa ur sikte. Den första riktar sig utåt mot de publika presentationerna och kan formuleras som: hur framträder kvinnor och män som subjekt och aktörer i de faktiska utställningarna. Den andra orienterar sig inåt mot museet självt och lyder: i vilken utsträckning utnyttjar museer sina samlingar och sitt kunnande för att utmana (och ibland också medvetet överskrida) traditionella tolkningar av manlighet och kvinnlighet? För annars står vi återigen där bland spjut, pilbågar och harpuner och för vidare uppfattningen att ett jägarfolk är detsamma som ett folk av jägare.

\section{NOTER}

1. Vi vill gärna understryka att denna förfrågan från Etnografiska museet var både framsynt och modig. Det tillhör inte vanligheterna att museerna bjuder in utanförstående för att granska den egna verksamheten. Det kan också nämnas att en pre- liminär version av denna granskning presentera-

des på Nationalmuseum vid museidagarna i mars 2007.

2. Samdok är ett nätverk och samarbetsorgan för kulturhistoriska museer som arbetar med samtidsstudier.

3, Eftersom vår granskning ligger ett antal år bakåt i tiden är flera av våra exempel numera inaktuella. Att vi ändå refererar till dessa äldre utställningskontexter beror på att vi menar att de speglar en mer generell problematik.

4. Med detta menar vi inte att kvinnor inte fiskat, jagat eller varit verksamma som bönder. Inte heller har vi ändrat uppfattning rörande kvinnornas arbete som en ofrånkomlig del av fisket, jakten eller bondevardagen. Vad vi säger är att dessa kvinnliga och alternativa aspekter av jakten, fisket osv däremot sällan uppmärksammas i utställningarna (både på Etnografiska och vid många andra museer).

\section{LITTERATUR}

Alpers, Svetlana: The Museum as a Way of Seing. Exhibiting Cultures. The Poetics and Politics of Museum Display. Ivan Karp och Steven Lavine (red). Smithsonian Institution Press: Washington 1991.

Bennett, Tony: The Birth of the Museum. History, Theory, Politics. Routledge: London 1995.

Brenna, Brita: Verden som ting og forestilling. Verdensutstillinger og den norske deltakelsen 1851 1900. Oslo universitet: Oslo 2002 (Diss).

Butler, Judith: Gender Trouble. Feminism and the Subversion of Identity. Routledge: New York 1990.

Butler, Judith: Bodies that Matter. On the Discursive Limits of "Sex". Routledge: New York 1993. Bäckman, Maria: "If our memory should fail us ..." SamdokBulletinen. Nr. 3, 1995: 11-14.

Eriksen, Anne: Museum. En kulturhistorie. Pax forlag: Oslo 2009. 
98 Gemzöe, Lena: Feminism. Bilda förlag: Stockholm 2003.

Grahn, Wera: "Känn dig själv": Genus, historiekonstruktion och kulturhistoriska museirepresentationer. Linköpings universitet: Linköping 2006 (Diss).

Grahn, Wera: Tekniska museet - den manliga teknikens tempel. Daedalus. Tekniska museets årsbok 2000. Tekniska museet: Stockholm 2000.

Gustafsson Reinius, Lotten: Bakom branddörren. Etnografiska samlingar som medier och materialitet. Mediernas kulturhistoria. Solveig Jülich, Patrik Lundell och Pelle Snickars (red). Statens ljud och bildarkiv: Stockholm 2008.

Haraway, Donna: Teddy Bear Patriarchy. Taxidermy in the Garden of Eden, New York City 1908-1936. Primate Visions. Gender, Race and Nature in the World of Modern Science. Routledge: London 1989.

Hirdman, Yvonne: Kvinnohistoriens historia. Genusperspektivets framväxt. Det dolda budskapet. Kön och makt-kvinnor och män i museiutställningar. Eva Persson (red). Seminarierapport från Arbetets museum och Riksutställningar: Norrköping 1994.

Knuts, Eva: Något gammalt, något nytt. Skapandet av bröllopsföreställhingar. Mara: Göteborg 2006 (Diss).

Kulick, Don: Inledning. Från kön till genus. Kvinnligt och manligt i ett kulturellt perspektiv. Don Kulick (red). Carlssons: Stockholm 1987.

Laqueur, Thomas: Om könens uppkomst. Hur kroppen blev kvinnlig och manlig. Brutus Östlings bokförlag, Symposion: Stockholm 1994.

Latour, Bruno och Michel Callon: Den store Leviatan isärskruvad. Hur aktörer makrostrukturerar verkligheten och hur sociologer hjälper dem att göra det. Artefaktens àterkomst. Ett möte mellan organisationsteori och tingens sociologi. Bruno Latour (red). Santérus förlag: Stockholm 1981.

Lundgren, Britta: Den bekönade kulturen. Kultur och erfarenhet. Aktuella teman i svensk etnologi. Billy
Ehn (red). Carlssons: Stockholm 1993.

Lundgren, Britta: Etnologiskt könsmedvetande. En fråga om makt. Det dolda budskapet. Kön och makt-kvinnor och män i museiutställningar. Eva Persson (red). Seminarierapport från Arbetets museum och Riksutställningar: Norrköping 1994.

Meurling, Birgitta och Inga-Lill Aronsson (red): Det bekönade museet. Genusperspektiv i museologi och museiverksamhet. Etnolore: Uppsala 2005.

Rosenberg, Tiina: Queerfeministisk agenda. Atlas Bokförlag: Stockholm 2002.

Samuelsson, Anna: I naturens teater. Kultur- och miljösociologiska analyser av naturhistoriska framställningar och bilder. Uppsala Universitet: Uppsala 2008 (Diss).

Wagner, Ulla: Vems röst är det vi hör? Med världen i kappsäcken. Samlingarnas väg till Etnografiska museet. Etnografiska museet: Stockholm 2002.

Östberg, Wilhelm: Museiföremål har många liv. Med världen i kappsäcken. Samlingarnas väg till Etnografiska museet. Etnografiska museet: Stockholm 2002.

* Maria Bäckman, forskare, docent $i$ etnologi

Adresse: Stockholms universitet, 10691 Stockholm

E-mail: Maria.backman@etnologi.su.se

*Simon Ekström, universitetslektor, docent $i$ etnologi

Adresse: Stockholms universitet, 10691 Stockholm

E-mail: Simon.ekstrom@etnologi.su.se 